\title{
Concentrations of Fat-soluble Vitamins of Trema guineensis Aqueous and Ethanolic Extracts and Rats Supplemented
}

\author{
Droucoula Guillaume Cyril ${ }^{1, *}$, Tra Bi Irié Otis ${ }^{1,2}$, Miezan Bile Aka Patrice ${ }^{1}$, Kouakou Sylvain Landry ${ }^{3}$, \\ Bla Kouakou Brice ${ }^{1}$, Yapi Houphouët Félix ${ }^{1}$ \\ ${ }^{1}$ Laboratory of Biochemical Pharmacodynamics, UFR Biosciences, Félix Houphouët-Boigny University, Côte d'Ivoire \\ ${ }^{2}$ Laboratory of SVT, Higher Teacher Training School of Abidjan, Côte d'Ivoire \\ ${ }^{3}$ Laboratory of Pharmacology, Clinical and Therapeutic Pharmacy, UFR Pharmaceutical and Biologic Sciences, \\ Félix Houphouët-Boigny University, Côte d'Ivoire
}

Copyright $\subseteq 2018$ by authors, all rights reserved. Authors agree that this article remains permanently open access under the terms of the Creative Commons Attribution License 4.0 International License

\begin{abstract}
This study was undertaken to determine vitamins A, D and E composition of aqueous and ethanolic extracts of Trema guineensis and effect of supplementation of these extracts on serum concentrations of these vitamins. Aqueous and ethanolic extracts of Trema guineensis were obtained by decoction and maceration of leaves powder, respectively. Then, they were administered to animals at doses of 100 and $200 \mathrm{mg} / \mathrm{kg}$ body weight against a control group treated with distilled water for two weeks. Composition of vitamins in extracts and serum concentrations of vitamins A, D and E were performed by HPLC. Results showed that Trema guineensis extracts contained high concentrations of vitamins A, D and E. Thus, vitamins A and D serum concentrations were weakly influenced while that of vitamin E increased strongly during administration of Trema guineensis extracts. This study therefore showed that extracts of Trema guineensis had vitamins A, D and E and a beneficial effect on serum concentrations of these vitamins.
\end{abstract}

Keywords Trema guineensis, Vitamins A, D and E, Côte d'Ivoire

\section{Introduction}

Vitamins are organic compounds essential to life. They are generally obtained in very small quantities by food and provide various biological functions [1]. Vitamins A, D and $\mathrm{E}$ constitute the class of fat-soluble vitamins [2]. Vitamin A refers to a group of compounds essential for vision, growth, cellular differentiation and proliferation, reproduction and immune system integrity [3]. It also has antioxidant properties [4]. Vitamin D plays a central role in calcium and phosphorus homeostasis and good skeletal formation [5]. Vitamin E is basically known as antioxidant. It protects cell membranes against oxidation caused by free radicals $[1 ; 6]$. Several work indicate that the serum disturbances of vitamins $\mathrm{A}, \mathrm{D}$ and $\mathrm{E}$ are often associated with hepatic, renal and hematologic pathologies $[7 ; 8 ; 9$; 10]. These vitamins could be found in plants whose biological activities have been studied. Trema guineensis is a plant used for feeding and various pathologies treatment $[11 ; 12 ; 13]$. Several studies showed that this plant has pharmacological properties such as nephroprotective [14], hepatoprotective [15] and antianemic activity [16] and chemical compounds that can justify its activities have been identified [17]. However, little information is available regarding the composition of vitamins $\mathrm{A}, \mathrm{D}$ and $\mathrm{E}$ in Trema guineensis leaves and effect of supplementation of this herbal extract on serum concentrations of these vitamins. Study objective was to find vitamins A, D and E in aqueous and ethanolic extracts of Trema guineensis and to determine effect of these extracts on serum concentrations of these vitamins.

\section{Materials and Methods}

\subsection{Collection and Extracts Preparation}

Trema guineensis leaves were collected from Abobo (Abidjan district) in January 2017. This plant was identified and authenticated by Botanical Department of Felix Houphouët Boigny University, Côte d'Ivoire. These leaves were dried at ambient temperature safe from light during two weeks then pulverized using an electric crusher (IKA-type $M \mathrm{GG}^{\mathbb{R}}$ ). The powder obtained, was useful for the various extractions. 


\subsection{Aqueous Extraction}

Hundred grams of plant powder was boiled in one Liter of distilled water for 10 minutes. The decoction was filtered twice on hydrophilic cotton and then once on filter paper Whatman $\mathrm{N}^{\circ} 3$. The filtrate was dried in an oven at $40^{\circ}$ C. $[18 ; 19]$.

\subsection{Ethanol Extraction}

Hundred grams powder of Trema guineensis leaves was macerated in one liter of the mixture ethanol-water $70 \%$ for 24 hours. The macerate was filtered twice on hydrophilic cotton and then once on filter paper Whatman $\mathrm{N}^{\circ} 3$. The filtrate was concentrated at a temperature of $40^{\circ} \mathrm{C}$ using a rotary evaporator Büchi-type and then dried in an oven at $40^{\circ} \mathrm{C}$. [20].

\subsection{Animals}

Healthy adult Wistar albino rats of mean weight $134.7 \pm$ $0.18 \mathrm{~g}$ were used for the study. These animals came from animal house of Pharmacology Laboratory of Training and Research Unit of Pharmaceutical and Biologic Sciences, Felix Houphouet Boigny University, Côte d'Ivoire where they were kept under favorable conditions of breeding and ethics. These rats were fed a standard complete food in the form of FACI (Fabrication d'Aliments de Cote d'Ivoire) pellets and drank tap water served ad libitum and renewed daily.

\subsection{Experimental Treatment}

Extracts administration was carried out according to method described by Adekunle et al. [21].

Thirty healthy rats divided into five groups of six animals were used for this study. These animals received daily gavage of distilled water or plant extracts with different doses for two weeks.

- Group control received distilled water for 14 days;

- Groups A 100 and A 200 were treated with aqueous extract Trema guineensis at respective doses of 100 $\mathrm{mg} / \mathrm{kg}$ and $200 \mathrm{mg} / \mathrm{kg}$ for 14 days;

- Groups E 100 and E 200 received ethanolic extract of Trema guineensis with respectively doses of 100 $\mathrm{mg} / \mathrm{kg}$ and $200 \mathrm{mg} / \mathrm{kg}$ for 14 days.

Each animal was anesthetized with ether and blood was collected from caudal vein on days 0, 7 and 14 (D0, D7 and D14). Blood was centrifuged at $3000 \mathrm{rpm}$ for 10 minutes (centrifuge B4i) to obtain serum, put in an eppendorf tube and protected by aluminum foil then stored at $-20^{\circ} \mathrm{C}$ until fat-soluble vitamins A, D and E analysis.

\subsection{Vitamins Analysis}

Vitamins A (retinol), D (calciferol) and E ( $\alpha$-tocopherol) concentrations were determined after extraction by high performance liquid chromatography (HPLC) of Waters ${ }^{\circledR}$ type in isocratic mode coupled with a fluorometric detector [22].

Fat-soluble vitamins were extracted from $0.5 \mathrm{~g}$ of extract or $0.5 \mathrm{~mL}$ of serum. To this quantity, $10 \mathrm{~mL}$ of a $10 \% \mathrm{KOH}$ solution are added in a methanol-water mixture $(1: 1 ; \mathrm{v} / \mathrm{v})$. Then $0.025 \mathrm{~g}$ of ascorbic acid was added to avoid oxidation process during saponification. Mixture is then refluxed in a water bath at $70^{\circ} \mathrm{C}$. for 30 minutes. After cooling mixture, $3 \times 5 \mathrm{~mL}$ of hexane was added. Hexanic phases were combined, dried over anhydrous sodium sulfate and evaporated to dryness. The residue obtained was taken up in methanol and $20 \mu \mathrm{l}$ of the methanol solution were injected into the chromatographic system for the quantitative analysis of the vitamins. Standard ranges were obtained from standard vitamin initial concentrations (vitamin A concentration: $0.9 \mathrm{mg} / \mathrm{mL}$, vitamin D concentration: $0.091 \mathrm{mg} / \mathrm{mL}$, vitamin E concentration: 2.8 $\mathrm{mg} / \mathrm{mL}$ ). Fluorometric detection of vitamins A, D and E was done at respective wavelengths of $455 \mathrm{~nm}, 245 \mathrm{~nm}$ and $295 \mathrm{~nm}$. Vitamins concentrations in sample are determined from peaks area of standard molecule and sample by following formula:

$$
\mathrm{CVs}=\frac{\mathrm{SVs} \times \mathrm{CVsr}}{\mathrm{SVsr}}
$$

CVs: concentration of vitamin in sample; SVs: peak area of the vitamin in sample; CVsr: concentration determined from standard range for each vitamin; SVsr: peak area corresponding to concentration vitamin selected from standard range.

\subsection{Statistical Analysis}

Values are expressed as mean \pm standard deviation (SD). Statistical analysis was carried out using the software GraphPad Prism 7. The analysis of the variances was performed using ANOVA followed by Tukey tests for comparison of vitamin concentrations in extracts and Dunnett for comparison of vitamins serum concentrations between different groups. The value of $p<0.05$ was considered significant.

\section{Results}

Concentrations of fat-soluble vitamins A, D and E in the Trema guineensis extracts have been shown in Table 1. Results revealed that vitamins A, D and E were present in aqueous and ethanolic extracts of Trema guineensis leaves but in variable amounts. The contents of vitamins A (1.798 $\pm 0.30 \mathrm{mg} / \mathrm{g}), \mathrm{D}(354.34 \pm 27.22 \mu \mathrm{g} / \mathrm{g})$ and $\mathrm{E}(3 \pm 0.28$ $\mathrm{mg} / \mathrm{g}$ ) of the extract ethanolic were high in comparison to those of vitamins A $(1.342 \pm 0.58 \mathrm{mg} / \mathrm{g}), \mathrm{D}(317.20 \pm 42.70$ $\mu \mathrm{g} / \mathrm{g})$ and $\mathrm{E}(2.08 \pm 0.66 \mathrm{mg} / \mathrm{g})$ in the aqueous extract. 
However, this difference was not significant. Fat-soluble vitamins in serum of rats supplemented with Trema guineensis extracts at doses of 100 and $200 \mathrm{mg} / \mathrm{kg}$ body weight and control group showed in Table 2. At day 0 (D0) there was no significant difference in vitamins concentrations between all groups. Administration of aqueous and ethanolic extracts of Trema guineensis to doses of 100 and $200 \mathrm{mg} / \mathrm{kg}$ body weight resulted in a non-significant increase in serum levels of vitamins $A$ and D on day 7 (D7) in comparison to control group. However, at day $14(\mathrm{D} 14)$, this increase was significant $(\mathrm{p}<0.05)$ in rats treated with aqueous and ethanolic extracts at a dose of $200 \mathrm{mg} / \mathrm{kg}$ body weight in comparison to control group rats. During treatment, the additional intake of Trema guineensis extracts to rats increased significantly $(\mathrm{p}<0.01$ and $\mathrm{p}<0.001)$ vitamin $\mathrm{E}$ serum levels in comparison to control group.

\section{Discussion}

Vitamin A provides a variety of functions throughout the body. These include: vision, gene transcription, immune function, embryonic development and reproduction, bone metabolism, hematopoiesis, skin and cell structure maintenance as well as antioxidant activity [23; 24]. Vitamin D contributes to phosphocalcic balance maintenance. It is essential for bone health and plays a role in gene expression, muscle and immune function $[25 ; 26$; $27 ; 28]$. Vitamin D induces several molecules expression such as glutathione and superoxide dismutase involved in antioxidant defense. It also has a direct antioxidant effect on cell membranes $[29 ; 30]$. Vitamin E, exclusively provided by diet, is a recognized antioxidant [31]. It also protects the membrane of red blood cells and limits the premature lysis of the erythrocytes [4]. Other known functions of vitamin $\mathrm{E}$ include enzymatic activities, gene expression, neurological function and cell signaling $[31 ; 32$; 33].

Compounds analysis showed that Trema guineensis leaves extracts contained vitamins $\mathrm{A}, \mathrm{D}$ and $\mathrm{E}$ with high amounts in ethanolic extract as aqueous extract. Other authors showed the presence of fat-soluble vitamins in various parts of plant [31; 34]. A level $(1.798 \pm 0.30 \mathrm{mg} / \mathrm{g}$ and $1.342 \pm 0.58 \mathrm{mg} / \mathrm{g}$ ) of ethanolic and aqueous extracts respectively were higher than that $(0.30 \pm 0.15 \mathrm{mg} / \mathrm{g})$ in Citrullus vulgaris Schrad extract reported by Hannah and Krishnakumari [35] and $(0.045 \pm 0.003 \mathrm{mg} / \mathrm{g})$ in Vitex chrysocarpa leaves obtained by Ilodibia et al. [36]. Vitamin D amounts $(317.20 \pm 42.70 \mu \mathrm{g} / \mathrm{g}$ and $354.34 \pm$ $27.22 \mu \mathrm{g} / \mathrm{g}$ ) in extracts of Trema guineensis was very high compared to that $0.0835 \mu \mathrm{g} / 100 \mathrm{~g}$ obtained in Canarium schweinfurthi pulp by Monanu et al. [31] works. Assi et al. [37] and Ajayi and Malachi [23] studies found vitamin E concentrations of $70.83 \pm 9.73 \mathrm{mg} / 100 \mathrm{~g}$ in Irvingia gabonensis almond consumed in Côte d'Ivoire and $49.43 \pm$ $0.58 \mathrm{mg} / 100 \mathrm{~g}$ in vegetable oil "Executive chef soybean" consumed in Nigeria. However, these values remained below vitamin $\mathrm{E}$ concentrations $(208 \pm 66 \mathrm{mg} / 100 \mathrm{~g}$ and $300 \pm 28 \mathrm{mg} / 100 \mathrm{~g}$ ) obtained from Trema guineensis leaves extracts. High content of fat-soluble vitamins observed in the aqueous extract is attributable to the rupture of the cell structure leaves by heat allowing the release of the micronutrients [31].

The aqueous and ethanolic extracts of Trema guineensis leaves administration to rats resulted in a small increase in serum vitamin A concentration after fourteen days of treatment. This result was in agreement with those of Raila et al. [38] who obtained a small increase in the serum concentration of vitamin A after vitamin A supplementation to animals. Also, Beketova et al. [39] reported a vitamin A serum concentration increase in rats following a supplementation of the Sunflower and Lard oil mixture. However, Yildirim et al. [40] reported no change in vitamin A serum concentration after the supplementation of Cocoa butter and Sunflower oil to rats. Treatment of rats by Trema guineensis extracts resulted in a large increase in serum concentrations of vitamins D and E. These results are supported by those of Jang et al. [41] who showed that supplementation of vitamins D and $E$ increased serum levels of these vitamins in pigs. Adekunle et al. [21] also observed a vitamin E serum increase in rats supplemented with Bryophyllum pinnatum. However, Yildirim et al. [40] showed no vitamin E concentration increase in serum of rats following supplementation of Cocoa butter and Sunflower oil.

Moreover, heat treatment as boiling also improves the availability of the vitamins A, D and E by destroying some anti-nutriments such as polyphenols and the tannins which interfered with the absorption of these compounds [42; 43; 44; 45]. In addition, Kouakou et al. [17] showed that the ethanolic extract of Trema guineensis was rich in phenolic compounds. Consequently, they would reduce bioavailability of vitamins $\mathrm{A}, \mathrm{D}$ and $\mathrm{E}$.

Increased serum levels of vitamins A, D and E after supplementation may prevent these vitamins disturbances in body. Also, it would justify some biological properties of Trema guineensis such as nephroprotective [14], hepatoprotective [15] and antianemic activity [16].

Table 1. Fat-soluble vitamins content of Trema guineensis extracts leaves

\begin{tabular}{cccc}
\hline & $\begin{array}{c}\text { Vitamin A } \\
(\mathrm{mg} / \mathrm{g})\end{array}$ & $\begin{array}{c}\text { Vitamin D } \\
(\mu \mathrm{g} / \mathrm{g})\end{array}$ & $\begin{array}{c}\text { Vitamin E } \\
(\mathrm{mg} / \mathrm{g})\end{array}$ \\
\hline $\begin{array}{c}\text { Aqueous } \\
\text { extract }\end{array}$ & $1.342 \pm 0.58$ & $317.20 \pm 42.70$ & $2.08 \pm 0.66$ \\
\hline $\begin{array}{c}\text { Ethanolic } \\
\text { extract }\end{array}$ & $1.798 \pm 0.30$ & $317.20 \pm 42.70$ & $3 \pm 0.28$ \\
\hline
\end{tabular}

Values are expressed as mean \pm standard deviation with $\mathrm{n}=3$. $\mathrm{P}>0.05$ : no significant difference between extracts. 
Table 2. Serum concentrations of vitamins A, D and E after administration of the extracts aqueous and ethanolic of Trema guineensis

\begin{tabular}{ccccccc}
\hline & & Control & A 100 & A 200 & E 100 & E 200 \\
\hline \multirow{3}{*}{ Vitamin A $(\mathbf{m g} / \mathbf{m L})$} & D0 & $0.85 \pm 0.16$ & $0.86 \pm 0.14$ & $0.84 \pm 0.06$ & $0.86 \pm 0.29$ & $0.84 \pm 0.03$ \\
\cline { 2 - 7 } & D7 & $0.88 \pm 0.14$ & $1.09 \pm 0.13$ & $1.17 \pm 0.05$ & $1.03 \pm 0.17$ & $1.13 \pm 0.02$ \\
\cline { 2 - 7 } & D14 & $0.91 \pm 0.17$ & $1.19 \pm 0.15$ & $1.31 \pm 0.05^{*}$ & $1.16 \pm 0.14$ & $1.28 \pm 0.35^{*}$ \\
\hline \multirow{3}{*}{ Vitamin D $(\boldsymbol{\mu g} / \mathbf{m L})$} & D0 & $8.36 \pm 0.89$ & $8.11 \pm 1.71$ & $8.33 \pm 0.32$ & $8.26 \pm 1.99$ & $8.84 \pm 0.23$ \\
\cline { 2 - 7 } & D7 & $8.94 \pm 0.24$ & $9.18 \pm 0.69$ & $9.49 \pm 0.57$ & $9.13 \pm 0.71$ & $9.36 \pm 0.82$ \\
\cline { 2 - 7 } & D14 & $8.98 \pm 0.97$ & $10.85 \pm 1.22$ & $11.80 \pm 2.60^{*}$ & $10.63 \pm 0.33$ & $11.65 \pm 1.61^{*}$ \\
\hline \multirow{3}{*}{ Vitamin E $(\boldsymbol{\mu g} / \mathbf{m L})$} & D0 & $66.07 \pm 1002$ & $63.35 \pm 18.21$ & $60.18 \pm 2.11$ & $65.03 \pm 2.18$ & $57.04 \pm 8.71$ \\
\cline { 2 - 7 } & D7 & $69.03 \pm 8.97$ & $82.94 \pm 3.11^{* *}$ & $89.76 \pm 1.70^{* * *}$ & $81.43 \pm 8.71^{* *}$ & $88.16 \pm 1.52^{* * *}$ \\
\cline { 2 - 6 } & D14 & $72.18 \pm 31.12$ & $117.15 \pm 7.04^{* * *}$ & $137.02 \pm 13.08^{* * *}$ & $115.43 \pm 4.11^{* * *}$ & $133.06 \pm 1.61^{* * *}$ \\
\hline
\end{tabular}

Values are expressed as mean \pm standard deviation with $\mathrm{n}=6$. $* \mathrm{p}<0.05 ; * * \mathrm{p}<0.01 ; * * * \mathrm{p}<0.001$. D0: day 0; D7: Day 7; D14: Day 14 ; Control: rats received distilled water; A 100 and A 200: groups treated with aqueous extract of Trema guineensis at doses of 100 and $200 \mathrm{mg} / \mathrm{kg}$ of body weight; E 100 and E 200: groups treated with Trema guineensis ethanolic extract at doses of 100 and $200 \mathrm{mg} / \mathrm{kg}$ of body weight

\section{Conclusions}

Vitamins A, D and E composition of aqueous and ethanolic extracts of Trema guineensis leaves and effect of these extracts on serum concentrations of these vitamins were determined in this study. Trema guineensis leaves extracts contain a high concentration of fat-soluble vitamins A, D and E. Thus, Trema guineensis extracts supplementation positively influences serum levels of vitamins A, D and $\mathrm{E}$. The presence of vitamins in leaves of Trema guineensis make this plant beneficial for health and justify its consumption and therapeutic use.

\section{Ethical Approval}

The experimental procedures were conducted after the approval of the Ethical Guidelines of University (Côte d'Ivoire) Committee on Animal Resources. All these procedures used, were in strict accordance with the guidelines for Care and Use of Laboratory Animals and the statements of the European Union regarding the handling of experimental animals (86/609/EEC).

\section{Competing Interests}

Authors have declared that no competing interests exist.

\section{REFERENCES}

[1] A.A. Iyanda, F. Adeniyi. Depletion in serum levels of folic acid, antioxidant vitamins and trace elements in female Wistar rats treated with sub-toxic dose of acetaminophen/methionine combination - a chronic study. British Journal of Pharmaceutical Research, 2(2):69-79, 2012.

[2] A.A. Albahrani, R.F. Greaves. Fat-Soluble Vitamins: Clinical Indications and Current Challenges for
Chromatographic Measurement. Clinical Biochemist Reviews, 37:27-47, 2016.

[3] A. Barua, M. Stacewicz-Sapuntzakis, H. Furr. Vitamin A retinol. In: Herrmann W, Obeid R, editors. Vitamins in the Prevention of Human Diseases. Walter de Gruyter, New York, pp. 7-39, 2011.

[4] P. Ravisankar, A. Reddy, B. Nagalakshmi, O.S. Koushik, B.V. Kumar, P.S. Anvith. The Comprehensive Review on Fat Soluble Vitamins. IOSR Journal of Pharmacy, 5(11):12-28, 2015.

[5] P. Terry, J.A. Baron, L. Bergkvist, L. Holmberg, A. Wolk Dietary calcium and vitamin D intake and risk of colorectal cancer: a prospective cohort study in women, Nutrition and Cancer, 43(1), 2002, 39-46.

[6] M.G. Traber. Vitamin E - Alpha-tocopherol. In: Herrmann $\mathrm{W}$, Obeid R, editors. Vitamins in the Prevention of Human Disease. Walter de Gruyter, Berlin, pp. 457-482, 2011.

[7] T.P. Paula, W.A.F. Feres, R.A. Ramalho, H.S.M. Coelho. Vitamin A metabolic aspects and alcoholic liver disease. Revista de Nutrição, 19:601-610, 2006.

[8] R.E. Schiff. Vitamin D deficiency and liver disease. Gastroenterology \& Hepatology, 6:491-493, 2010.

[9] R.F. Greaves, G.A. Woollard, K.E. Hoad, T.A. Walmsley, L.A. Johnson, S. Briscoe, S. Koetsier, T. Harrower, J.P. Gill. Laboratory Medicine Best Practice Guideline: Vitamins A, $\mathrm{E}$ and the Carotenoids in Blood. Clinical Biochemist Reviews, 35:81-114, 2014.

[10] N.A. Shamseldin, E.A.M. Mohammed. Effect of 25-hydroxy Vitamin D and Hemodialysis on Vitamin D Axis in Sudanese Renal Failure Patients. International Journal of Biochemistry Research \& Review, 13:1-8, 2016.

[11] F.R. Irvine. Woody plants of Ghana: with special reference to their uses. Oxford University Pres, London, 869 p, 1961.

[12] A.G.N. Fongod, M.C. Veranso, M.N. Libalah. Identification and use of plants in treating infertility in human females in Fako Division, Cameroon. Global Journal of Research on Medicinal Plants \& Indigenous Medicine, 2(11):724-737, 2013.

[13] K. Béné, D Camara, N.B.Y. Fofié, Y. Kanga, A.B. Yapi, Y.C. Yapo, S.A. Ambe, G.N. Zirihi. Étude ethnobotanique 
des plantes médicinales utilisées dans le Département de Transua, District du Zanzan (Côte d'Ivoire). Journal of Animal \&Plant Sciences, 27(2):4230- 4250, 2016.

[14] G.C. Droucoula, S.L. Kouakou, Y.K.F. Kouakou, A. Bamba, H.F. Yapi, A.T. Okpekon. Evaluation of Nephroprotective Activity of Aqueous and Hydroethanolic Extracts of Trema guineensis Leaves (Ulmaceae) against Gentamicin-Induced Nephrotoxicity in Rats. International Journal of Biochemistry Research \& Review, 15(2):1-10, 2016.

[15] G. C. Droucoula, A.T. Okpekon, S.L. Kouakou, B.A.P. Miezan, B.N. Djyh, K.B. Bla, G. Kouakou-Siransy, H.F. Yapi. Protective effect of Trema guineensis extracts on $\mathrm{CCl}_{4}$-induced hepatotoxicity. IOSR Journal of Biotechnology and Biochemistry, 3(2):5-9, 2017.

[16] G.C. Droucoula, S.L. Kouakou, B.A.P. Miezan, D.P. Tchimon, H.F. Yapi. Antianemic properties of Trema guineensis aqueous and ethanolic extracts. European Journal of Biotechnology and Bioscience, 5(2):20-24, 2017.

[17] Y.K.F. Kouakou, G. Gnahoué, H.F. Yapi, A.E. Aka, J.D. N'guessan, A.J. Djaman. Toxicological and phytochemical screening study of Trema guineensis (Ulmaceae), plant of Côte d'Ivoire (West Africa). World Journal of Pharmaceutical Research, 3(8):12-23, 2014.

[18] J. Nemlin, J.F. Brunel. Fascicule de Travaux Pratiques de Matière Médicale (3ème année). Université Nationale de Côte-d'Ivoire. Faculté de Pharmacie. Département de Pharmacognosie. Laboratoire de Phytologie, 47 p, 1995.

[19] N.G. Konkon, A.L. Adjoungoua, P. Manda, D. Simaga, K.E. N'Guessan, B.D. Kone. Toxicological and phytochemical screening study of Mitragyna Inermis (willd.) O ktze (Rubiaceae), antidiabetic plant. Journal of Medicinal Plants Research, 2(10):279-284, 2008.

[20] F. Guédé-guina, M. Vangah-manda, D. Harouna, C. Bahi. Potencies of Misca, a plant source concentrate against fungi. Journal of Ethnopharmacology, 14:45-53, 1993.

[21] A.S. Adekunle, T.I. Adelusi, E.B. Oyewo, J-P. Kamdem, B.B. Akintade. Antihypercholesterolemic, Cardioprotective and Vitamins E and C Sparing Properties of Bryophyllum pinnatum in Rabbits. European Journal of Medicinal Plants, 11(3):1-13, 2016.

[22] A. Jedlička, J. Klimeš. Determination of Water- and Fat-Soluble Vitamins in Different Matrices Using High-Performance Liquid Chromatography. Chemical Papers, 59 (3):202-222, 2005.

[23] O.B. Ajayi, O.I. Malachi O. I. Comparative Study of Phytosterols and Vitamins A and E Composition of Vegetable Oil Brands Consumed in Nigeria. International Journal of Biochemistry Research \& Review, 11(4):1-6, 2016.

[24] G. Duester. Retinoic acid synthesis and signaling during early organogenesis. Cell, 134(6):921-931, 2008.

[25] J.W. Pike, M.R. Meyer. The vitamin D receptor: new paradigms for the regulation of gene expression by 1,25-dihydroxyvitamin $\mathrm{D}(3)$. Endocrinology Metabolism Clinics of North America, 39:255-269, 2010.

[26] M.R. Haussler, P.W. Jurutka, M. Mizwicki, A.W. Norman. Vitamin D receptor (VDR)-mediated actions of $1,25(\mathrm{OH})_{2}$ vitamin $\mathrm{D}_{3}$ : genomic and non-genomic mechanisms. Best Practice \& Research Clinical Endocrinology \& Metabolism, 25:543-559, 2011.

[27] D.D. Bikle. Vitamin D metabolism, mechanism of action, and clinical applications. Chemistry \& Biology, 21(3):319-329, 2014.

[28] X. Zhang, F. Ding, H. Li, W. Zhao, H. Jing, Y. Yan, Y. Chen. Low Serum Levels of Vitamins A, D, and E Are Associated with Recurrent Respiratory Tract Infections in Children Living in Northern China: A Case Control Study. PLoS ONE, 11(12):1-9, 2016.

[29] H. Wiseman. Vitamin D is a membrane antioxidant. Ability to inhibit iron-dependent lipid peroxidation in liposomes compared to cholesterol, ergosterol and tamoxifen and prelevance to anticancer action. FEBS Letters, 326:285-288, 1993.

[30] Z. Mokhtari, A. Hekmatdoost, M. Nourian. Antioxidant efficacy of vitamin D. Journal of Parathyroid Disease, 5(1):11-16, 2017.

[31] M.O. Monanu, E.A. Anyalogbu, E.N. Onyeike. Effect of Maceration Time on Micronutrient Concentrations of Canarium schweinfurthii Pulp Flour. Advances in Research, 2(11):605-617, 2014.

[32] J.M. Zingg, A. Azzi. Non-antioxidant activities of vitamin E. Current Medicinal Chemistry, 11:1113-1133, 2004.

[33] A. Azzi. Molecular mechanism of alphatocopherol action. Free Radical Biology \& Medicine, 43(1):16-21, 2007.

[34] G. Asghari, A. Palizban, B. Bakhshaei. Quantitative analysis of the nutritional components in leaves and seeds of the Persian Moringa peregrina (Forssk) Fiori. Pharmacognosy Research, 7(3):242-248, 2015.

[35] M.A.C. Hannah, S. Krishnakumari. Profiling of Lipid and Vitamin contents in the extract of Watermelon (Citrullus vulgaris Schrad.) seeds. Journal of Pharmacognosy and Phytochemistry, 4(3):247-252, 2015.

[36] C.V. Ilodibia, E. Eze, M.U. Chukwuma, E.E. Akachukwu, N.A. Igboabuchi, R.N. Adimonyemma. Proximate, Vitamin, Mineral and Anatomical Studies on Vitex chrysocarpa Planch ex Benth. (Verbenaceae). Journal of Advances in Biology \& Biotechnology, 9(1):1-5, 2016.

[37] O.Y. Assi, A. Coulibaly, P. Kouakou, N.Y. Konan, O. Chatigre, G.H. Biego. Vitamins Contents in Edible Parts of Some Mucilaginous Food Plants from Côte d'Ivoire. Journal of Advances in Biology \& Biotechnology, $10(2): 1-14,2016$.

[38] J. Raila, R. Radon, A. Trüpschuch, F.J. Schweigert. Retinol and retinyl ester responses in the blood plasma and urine of dogs after a single oral dose of vitamin A. Journal of Nutrition, 132:1673S-1675S, 2002.

[39] N.A. Beketova, O.A. Vrzhesmskaya, V.M. Kodentsova, O.V. Kosheleva, G.V. Guseva, N.V. Trusov. Effect of diet fat content on vitamin status of rats. Voprosy Pitaniia, 81(3):52-57, 2012.

[40] E. Yildirim, M. Çinar, E. Yalçinkaya, H. Ekici, N. Atmaca, E. Güncüm. Effect of Cocoa Butter and Sunflower Oil Supplementation on Performance, Immunoglobulin, and Antioxidant Vitamin Status of Rats. BioMed Research International, 2014:1-8, 2014. 
[41] Y.D. Jang, M.D. Lindemann, H.J. Monegue, R.L. Stuart. The effects of fat-soluble vitamin administration on plasma vitamin status of nursing pigs differ when provided by oral administration or injection. Asian-Australasian Journal of Animal Sciences, 27(5):674-682, 2014.

[42] A. Musa, E.O. Ogbadoyi. Effect of processing methods on some micronutrients, antinutrients and toxic substances in Hibiscus sabdariffa. Asian Journal of Biochemistry, 7(2):63-79, 2012.

[43] B.J. Akinyele, O.S. Oloruntoba. Comparative studies on Citrullus vulgaris, Citrullus colocynthis and Cucumeropsis mannii for 'Ogiri' production. British Microbiology Research Journal, 3(1):1-18, 2013.

[44] I.I. Udousoro, R.U. Ekop, E.J. Udo. Effect of thermal processing on antinutrients in common edible green leafy vegetables grown in Ikot Abasi, Nigeria. Pakistan Journal of Nutrition, 12(2):162-167, 2013.

[45] E.I. Uwah, E.A. Moses, K.R. Okokon. Proximate, minerals and anti-nutrients composition of two leafy vegetables commonly consumed in idu, uruan, akwa ibom state, nigeria. International Journal of Current Research in Chemistry and Pharmaceutical Sciences, 2(10):24-30, 2015. 